\title{
Phytoremediation of Crude Oil Contaminated Soil with Axonopus compressus in the Niger Delta Region of Nigeria
}

\author{
Efe Sunday Ighovie ${ }^{1}$, Elenwo Ephram Ikechukwu ${ }^{2}$ \\ ${ }^{1}$ Department of Geography and Regional Planning, Delta State University, Abraka, Nigeria; ${ }^{2}$ Department of Geography and Envi- \\ ronmental Management, University of Port Harcourt Choba, Port Harcourt, Nigeria. \\ Email: ighovieefe@yahoo.com, iyke2_elenwo@yahoo.com
}

Received December $12^{\text {th }}, 2013$; revised January $17^{\text {th }}, 2014$; accepted January $29^{\text {th }}, 2014$

Copyright (c) 2014 Efe Sunday Ighovie, Elenwo Ephram Ikechukwu. This is an open access article distributed under the Creative Commons Attribution License, which permits unrestricted use, distribution, and reproduction in any medium, provided the original work is properly cited. In accordance of the Creative Commons Attribution License all Copyrights (C) 2014 are reserved for SCIRP and the owner of the intellectual property Efe Sunday Ighovie, Elenwo Ephram Ikechukwu. All Copyright (C) 2014 are guarded by law and by SCIRP as a guardian.

\section{ABSTRACT}

The study assessed the effectiveness of carpet grass (Axonopus compressus) in the phytoremediation management of oil impacted soil in Ubeji and Alesa Eleme communities of Niger Delta region of Nigeria. To achieve this, the study employed an experimental research design that involved the use of Axonopus compressus in the management of oil-impacted soil sites of Ubeji and Alesa Eleme. This experiment lasted for four months' period (one planting season). Axonopus sp. was used for the treatment of the crude oil impacted sites. Laboratory analysis of the soil samples was conducted to determine the effect of phytoremediation on hydrocarbon, acidity, organic matter and moisture loss in oil impacted sites. The study revealed that the use of Axonopus sp. resulted in $66 \%$ loss of hydrocarbon from crude oil-impacted soils of Ubeji and Alesa Eleme. However, there is no significant difference in crude oil loss in the soils of Ubeji and Alesa Eleme as a result of Axonopus sp. This could be ascribed to the similarities in soil properties and climate type of the Niger Delta region of Nigeria. It also showed that the growth of Axonopus sp. in the crude oil-impacted soils of Ubeji and Alesa Eleme has reduced the acidity of hydrocarbon content in soils (4.46 - 6.87 $\mathrm{pH}$ in Ubeji and 4.66 - 6.86 $\mathrm{pH}$ in Alesa Eleme) from the first day to the $90^{\text {th }}$ days of experiment, and thereafter there was stabilization at the $4^{\text {th }}$ month. This indicates that acidity in soil increases (lower $\mathbf{p H}$ ) with increase in the concentration of crude oil in soils. However, the adoption of Axonopus sp. in hydrocarbon-impacted soils has increased the $\mathrm{pH}$ of soils, and enhanced the accumulation of organic matter and moisture content in oil-impacted soils of Ubeji and Alesa Eleme. The implication of the findings is that Axonopus sp. has the tenacity to phytoremediate hydrocarbon concentration in soil effectively in any geographical region of the world; as such, it is recommended for adoption by oil companies, government and nongovernmental organization agency for the remediation of oil spill sites.

\section{KEYWORDS}

Axonopus sp.; Phytoremediation; Crude Oil; Impacted Soil

\section{Introduction}

Over the world, about 8.8 million of metric tonnes of crude oil are released into the world water and soil. And out of this, $90 \%$ is responsible for human activities of oil spillage and deliberate discharge of waste into soil and water bodies [1]. And the oil rich Niger Delta region of Nigeria has been characterized by petroleum exploration, exploitation and production activities and hence, daily predisposed to oil pollution of varying magnitudes. For instance, since commercial exploration of petroleum started in Nigeria in 1958, the land, water bodies and marshes have become heavily polluted due to accumulation from several years of incipient and perceived pollution of the ecosystem. According to UN report, it is believed that an average riverine dweller of the Niger Delta region of Nigeria is exposed to polluted air, polluted water and polluted food, thus resulting in health hazard that reduces life expectancy [2]. Also the agricultural lands have be- 
come less productive, and the creeks and the fishing waters have become more or less dead as well as series of civil unrests witnessed in the region due to environmental degradation of oil exploration [3-6].

[7] opined that oil exploration and exploitation have over the last four decades impacted disastrously on the socio-physical environment of the Niger-Delta oil bearing communities, massively threatening the subsistent peasant economy and the environment and hence, the entire livelihood and basic survival of the people. However, attempts at clean up of oil contaminated sites in the region have been the physical, chemical and thermal process techniques [8-10]. However, these techniques have some adverse effects on the environment and are also expensive $[8,11]$.

Petroleum contaminated soil can be revamped by different methods which include physico-chemical and biological approaches. Compared to physico-chemical methods, bioremediation is thought to be low cost, low environmental risk but longer time needed [12]. A variety of bioremediation methods have been developed to increase the degradation rate of petroleum in soil. Isolation of effective microorganisms has been well studied and proved to be effective method in bioremediation of petroleum polluted soil [12-14]. However, phytoremediation has shown that several pollutants of petroleum products and solvents, are degraded faster in the presence of plants in which transpiration of water, oxygen transport, biological stimulation in the root zone and plant uptake of chemicals are thought to be influencing factors [12,15]. On the same vein, microbial numbers in the vegetated soil were significantly higher than those in the unvegetated soils in the rhizosphere [16-18].

Phytoremediation is the use of plants and/or associated microorganisms to remove or render harmful material harmless or to detoxify oil polluted sites [19-22]. It has been shown to be effective for different kinds of contaminants like heavy metals, radionuclides and broad range of organic pollutants [23]. [24] asserted that plants for phytoremediation should be appropriate for the climate and soil conditions of the contaminated sites. The plants should also have the ability to tolerate conditions of stress [25]. Several plant species have been used for phytoremediation drivers, and these plants are: grasses, legumes, trees and several other monocots and dicots [25,26].

Attempts have been made to use some plants to remediate oil polluted in Nigeria [see 9,10,21]. While [27], carried his work in Port Harcourt for six weeks, and demonstrated the use of Zea mays (corn) and Pennisetum purpureum (elephant grass) in degrading petroleum hydrocarbons in contaminated agricultural soils, and found an average hydrocarbon losses of $77.5 \%$ (Z. mays) and 83\% ( $P$. purpureum) within the first two weeks. These values decreased to $67.5 \%$ and $55 \%$ after the six-week remediation period for corn and elephant grass respectively. [10] in the study of Ekpan which lasted for three months' uses of Axonopus sp., Cyperus sp. and soil amendments, it was found that the combined effect of Axonopus $s p$., Cyperus sp. and oil amendments accounted for 59\% reduction in hydrocarbon. However, Axonopus sp. and Cyperus sp. accounted for $47 \%$ and $48 \%$ reduction in hydrocarbon respectively. These scholars therefore call for similar studies with more weeks/months of study adopted in order to effectively validate the use of these plants for the remediation of hydrocarbon contaminated soil. Though this technology appears to be promising, not much has been done in Nigeria and in Niger-Delta region in particular. On this premise, this study is aimed at assessing the effectiveness of Axonopus sp. phytoremediation measure of crude oil contaminated soil of the Niger Delta region of Nigeria.

\section{Study Area}

The Niger Delta region of Nigeria falls within the central coastlands of southern Nigeria. It lies at the intersection of latitude $5^{\circ} 31 \mathrm{~N}$ and $5^{\circ} 33 \mathrm{~N}$ and longitude $5^{\circ} 30 \mathrm{E}$ and $5^{\circ} 32 \mathrm{E}$. The region is divided into two subdivision, western and eastern region (see Figure 1), and one third of the region is made up of wetlands and house the third largest mangrove forest in the world [28], with some seven million people that live in the 70,000 square kilometer. While Ubeji is located close to Warri Petroleum and Refinery Company (WPR C) in the western region, the Port Harcourt Petroleum and Refinery Company (PPRC) is located at Alesa Eleme (see Figure 1). The region has been described as a gas province, and over $75 \%$ of it natural gas is fared [29]. The region is characterized with subequatorial climate, but this climate has been influenced by the gas flaring in this region with higher temperatures observed closed to gas flare sites. Rainfall is over $2450 \mathrm{~mm}$ to over $3000 \mathrm{~mm}$ per year with no dry season, as rain in all months is over $2.5 \mathrm{~cm}$ and often precipitate acid rain [30] (see Figure 1). Relative humidity is normally over $90 \%$ in the mornings, but drops to $80 \%$ in the afternoons [28,31]. The wet land nature has encouraged the retention of crude oil on the surface soil for long period of time whenever there is oil spill.

\section{Methods of Data Collection}

The study employed an experimental research design which involves the release of crude oil on the soil and the use of carpet grass plant (Axonopus sp.) as phytoremediation method in the management of petroleum impacted soil in Ubeji and Elesa Eleme for four months periods. It involves treatment of the oil impacted sites with Axonopus sp. grass plant. Axonopus compressusz is a perennial, 


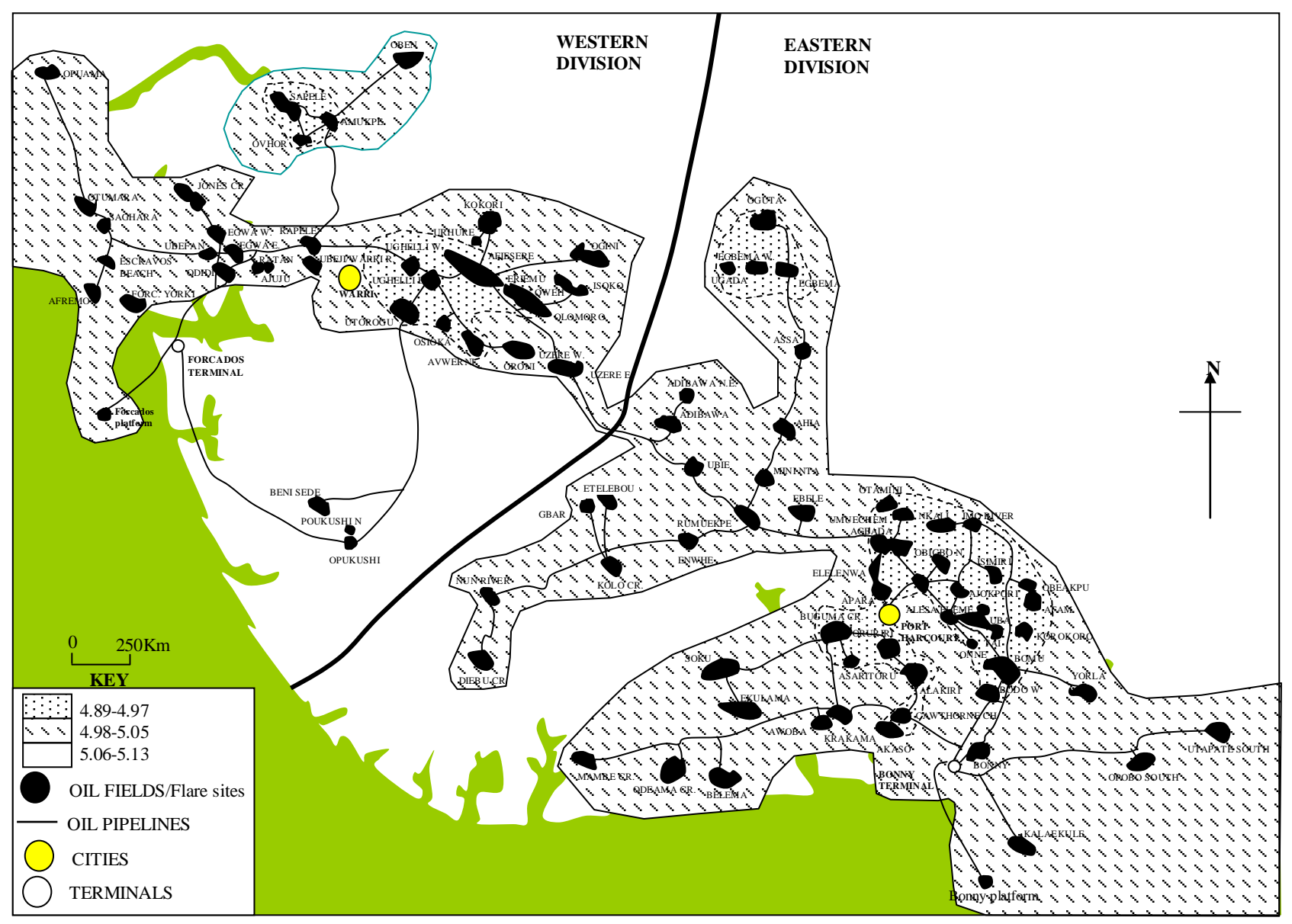

Figure 1. Spatial distribution of flare sites/acid rain in Niger delta.

coarse-leaved, creeping grass (see Figure 2). It grows better on low, wet soils than do other grasses. This plant was selected based on certain features thought to enhance phytoremediation. These include the ability of the plant to survive adverse environmental conditions, fibrous root system and high rate of evapo-transpiration to enhance phytostabilization. It grows well in either sun or shade but is less shade tolerant than St. Augustine and Centipede grass which it resembles [10]. These features enhanced the ability of these plants to remove oil from the spill sites. Two experimental plots each were established at Ubeji and Alesa Eleme, and Axonopus sp. grass plant was planted at one plot, while the other plot is without Axonopus sp. grass plant. A total of five soil samples each were collected from Ubeji and Elesa Eleme for laboratory analysis. One soil samples was collected from each plot at the beginning of the experiment and every $30^{\text {th }}$ days of a month until the fourth months of the experiment for laboratory analysis of TOG, expressed in milligram per kilogram of soil sample (mg/kg).

The crude impacted sites used for this research were tilled with the aid of shovels to loosen the soil and also enhance aeration. The tilled soil was then mixed, using rakes; this was to further homogenize the soil in order to create favourable condition for plant growth. The use of rake was also intended to obtain a near uniform concentration of petroleum hydrocarbon in the experimental plots. The cultivated/tilled experimental plots were then divided into two sub-plots about $2 \mathrm{~m} \times 1.5 \mathrm{~m}$ by means of furrows between the flat ridges. The sub-plots were labelled $\mathrm{A}-\mathrm{B}$, based on the number of treatments intended for the study. Section A indicates the control that is soil that contains crude oil without Axonopus sp. While B is the soil section with crude oil and treated with Axonopus sp. Soil samples were then collected at the surface and $150 \mathrm{~mm}$ depth at the $1^{\text {st }}$ day and every 30 days. These soils were mixed together and used for the determination of soil $\mathrm{pH}$, organic matter and moisture. Laboratory analysis of the soil samples was conducted to determine the effect of phytoremediation on hydrocarbon loss, soil $\mathrm{pH}$, organic matter and moisture content in oil impacted sites. The $\mathrm{pH}$ of the soils was determined following the pattern outlined by [32]. In line with [33] method, the soils were air dried and sieved to remove large particles and debris. $5 \mathrm{~g}$ of the sieved soils were mixed with $5 \mathrm{mls}$ of distilled water and stirred very well after which mixture was al- 
lowed to stand for 30 minutes. The electrode of a $\mathrm{pH}$ meter was put into slurry of the soil-water mixture and the $\mathrm{pH}$ of the soil was read off. And the moisture and organic matter content of the soil were determined following the procedures of [33-35] respectively.

The total amount of oil and grease (TOG) in the soil samples was determined using air-dried soils, sieved through $1 \mathrm{~mm}$ mesh. The TOG in the soil was first extracted with n-hexane in line with $[10,36]$ methods. The soil-crude oil-n-hexane mixture was filtered into a beaker of known weight through a Whatmann No.1 filter paper. The TOG content of the filtrate was determined after heating the beaker at $40^{\circ} \mathrm{C}$ to a constant weight in line with $[9,22]$. The amount of hydrocarbon lost from the soil was determined as the amount of TOG added to the soil minus that in the soil at the time of analysis. The effect of Axonopus sp. on the $\mathrm{pH}$, moisture, organic matter and crude oil contents of the soils were determined by comparing each parameter in soil with Axonopus sp. with that of the soil without Axonopus sp. The data obtained were analyzed with descriptive statistics, paired test and correlation analyses and run with the statistical package for the social sciences version 15 .

\section{Results and Discussion}

This section discusses the data generated for this study. Tables 1-4 showed the concentration of petroleum hydrocarbon or total oil and grease (TOG) in soil, and its effect on soil $\mathrm{pH}$, organic matter and moisture content of the soil of Ubeji in Delta state and Alesa Eleme in Rivers state. Table 1 reveals that Axonopus sp. and its associated micro organisms are capable of reducing the concentration of petroleum hydrocarbon in oil impacted soil. It showed clearly that there is a gradual loss in the concentration of petroleum hydrocarbon in soil from the beginning $(3678.23 \mathrm{mg} / \mathrm{kg})$ to the end of the experiment (1262.41 mg/kg and 2415.74) at Ubeji and Alesa Eleme respectively. Generally the study revealed $66 \%$ loss of hydrocarbon at the end of the four months observation in Ubeji and Alesa Eleme as result of Axonopus sp (see
Table 1). This loss showed a significant correlation value of 0.98 , which is significant at $p>0.05$ (see Figures 3 and 4). This showed that phytoremediation has significantly reduced the concentration of petroleum hydrocarbon from the impacted soil of Ubeji and Alesa Eleme (see Table 1). This is also evident in the trend lines in Figures 3 and 4. This finding agrees with [10,37] who reported that phytoremediation can be effectively used to manage soil contaminated with petroleum hydrocarbon. There is also gradual reduction in petroleum hydrocarbon in the soil without Axonopus sp. Hydrocarbon in this site decreases from $3678.23 \mathrm{mg} / \mathrm{kg}$ at the beginning to $2812.45 \mathrm{mg} / \mathrm{kg}$ and $2812.54 \mathrm{mg} / \mathrm{kg}$ at Ubeji and Alesa Eleme respectively. This indicates $865.78 \mathrm{mg} / \mathrm{kg}$ and $865.69 \mathrm{mg} / \mathrm{kg}$ (24\%) loss in total oil and grease in soil of Ubeji and Alesa Eleme respectively in the control site without Axonopus sp. (see Table 1), this natural attenuation is precipitated by atmospheric influence [10]. This result corroborated those studies of Axonopus sp. and other plants in Table 2. In particular with those of [38] (85\% for Cyperus laxus lam), [39] (50\% for Festuca rubra), [40] (70\% for sedge), [41] (30\% - 50\% for Altai wild rye AWR and alfalfa) and 10] (47\% for Axonopus $s p$.). It also corroborated [42-44]. [10] study of Ekpan lasted for three months and accounted for $47 \%$ reduction in TOG by Axonopus sp., while this study of Ubeji and Alesa

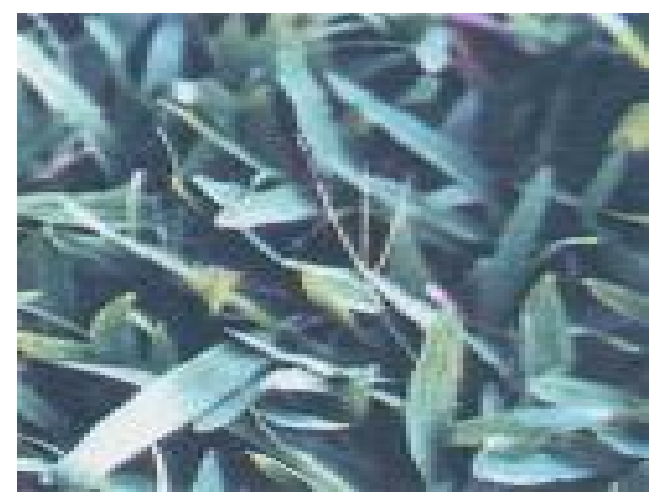

Figure 2. Axonopus sp.

Table 1. Hydrocarbon in impacted soil under Axonopus sp. in Ubeji and Alesa Eleme.

\begin{tabular}{|c|c|c|c|c|c|c|c|c|}
\hline \multirow[b]{2}{*}{$\begin{array}{l}\text { Days of } \\
\text { sample }\end{array}$} & \multicolumn{4}{|c|}{ Ubeji } & \multicolumn{4}{|c|}{ Alesa Eleme } \\
\hline & $\begin{array}{l}\text { Control TOG } \\
\text { (mg/kg) }\end{array}$ & $\begin{array}{l}\text { TOG with } \\
\text { Axonopus sp. } \\
\text { (mg/kg) }\end{array}$ & $\begin{array}{l}\text { HC loss } \\
(\mathrm{mg} / \mathrm{kg})\end{array}$ & $\begin{array}{c}\% \text { HC loss } \\
\text { from Initial } \\
\text { TOG }\end{array}$ & $\begin{array}{l}\text { Control } \\
\text { TOG } \\
\text { (mg/kg) }\end{array}$ & $\begin{array}{c}\text { TOG with } \\
\text { Axonopus sp. } \\
\text { (mg/kg) }\end{array}$ & $\begin{array}{l}\text { HC loss } \\
(\mathrm{mg} / \mathrm{kg})\end{array}$ & $\begin{array}{l}\% \text { HC from } \\
\text { initial TOG }\end{array}$ \\
\hline 1 & 3678.23 & 3678.23 & 0.00 & 0 & 3678.23 & 3678.23 & 0.00 & 0 \\
\hline 30 & 3464.30 & 3074.19 & 390.11 & 11 & 3464.33 & 3074.25 & 603.98 & 17 \\
\hline 60 & 3253.13 & 2471.23 & 1207 & 33 & 3254.02 & 2472.00 & 1206.23 & 33 \\
\hline 90 & 3035.16 & 1863.34 & 1814.89 & 49 & 3035.24 & 1864.03 & 1814.2 & 49 \\
\hline 120 & 2812.45 & 1262.41 & 2415.82 & 66 & 2812.54 & 1262.49 & 2415.74 & 66 \\
\hline
\end{tabular}


Phytoremediation of Crude Oil Contaminated Soil with Axonopus compressus in the Niger Delta Region of Nigeria

Table 2. Bioremediation studies.

\begin{tabular}{|c|c|c|c|}
\hline $\mathrm{s} / \mathrm{n}$ & Bioremediation methods & Degradation rate & References \\
\hline 1 & Ryegrass + plant growth rhizobacterial (PGPR) & 3 year, $61.5 \%$ & [42] Gurska et al., 2009 \\
\hline 2 & Astragalusadsurgens + microorganism & $>67 \%, 13 \%-30 \%$ higher than that of plant alone & [44] Xin et al., 2008 \\
\hline 3 & Creeping red fescue (Festuca rubra) & $\begin{array}{l}50 \% \text { reduction in total petroleum hydrocarbon } \\
\text { after } 4 \text { - } 5 \text { months }\end{array}$ & [39] Philips et al., 2006 \\
\hline 4 & Cyperus laxus lam & 90 for inoculated and $85 \%$ for non-inoculated & $\begin{array}{l}\text { [38] Escalante-Espinosa et al., } \\
2005\end{array}$ \\
\hline 5 & $\begin{array}{c}\text { Phytoremidiation by tall wheat grass, Altai wild } \\
\text { rye AWR and alfalfa }\end{array}$ & $30 \%-50 \%$ & [41] Philips et al., 2009 \\
\hline 6 & Phytoremidiation with graminaceous plants & 150d: 2.33 - 3.19 times higher than control & [43] Zhang et al., 2009 \\
\hline 7 & $\begin{array}{l}\text { Phytoremediation with willow (salice exigua), } \\
\text { popliar (populus spp.), eastern gama grass } \\
\text { (tripsacul dactyloides), arrowhead (sagitaria } \\
\text { latifolia), switch grass (panicum virgatum), and } \\
\text { sedg (carex stricta) }\end{array}$ & $\begin{array}{c}1 \text { year } 70 \% \text { for sedge, switchgrass, gamagrass, and } \\
20 \% \text { for willow, poplar, or no plant }\end{array}$ & [40] Euliss et al., 2008 \\
\hline 8 & $\begin{array}{l}\text { Phytoremediation with cyperus sp., axonopus sp. } \\
\text { and soil amendments }\end{array}$ & $59 \%$ reduction in total hydrocarbon after 3 months & [10] Efe and Okpali, 2012 \\
\hline 9 & Phytoremediation with cyperus sp. & $48 \%$ reduction in total hydrocarbon after 3 months & [10] Efe and Okpali, 2012 \\
\hline 10 & Phytoremediation. axonopus sp. & $47 \%$ reduction in total hydrocarbon after 3 months & [10] Efe and Okpali, 2012 \\
\hline 11 & Phytoremediation. cyperus sp.and axonopus sp. & $53 \%$ reduction in total hydrocarbon after 3 months & [10] Efe and Okpali, 2012 \\
\hline 12 & Phytoremediation. axonopus sp & $66 \%$ reduction in TOG after 4 months & Author’ field work, 2013 \\
\hline
\end{tabular}

Source: Modified after [10,12].

Table 3. Paired t' test explaining the differences in loss of TOG soil of Ubeji and Alesa Eleme.

\begin{tabular}{|c|c|c|c|c|c|c|c|c|c|}
\hline & \multicolumn{2}{|c|}{ Paired differences } & \multirow[b]{2}{*}{ Std. error Mean } & \multicolumn{2}{|c|}{$\begin{array}{l}\text { 95\% confidence interval of } \\
\text { the difference }\end{array}$} & \multirow{2}{*}{$\mathrm{T}$} & \multirow{2}{*}{ Critical t } & \multirow{2}{*}{ Df } & \multirow[t]{2}{*}{$\mathrm{R}$} \\
\hline & Mean & Std. Deviation & & Lower & Upper & & & & \\
\hline Ubeji-Alesa Eleme & -42.4660 & 95.81838 & 42.85128 & -161.440 & 76.50823 & -0.991 & 2.776 & 4 & 0.996 \\
\hline
\end{tabular}

Table 4. Effect of Axonopus sp. on the pH of oil polluted Soil.

\begin{tabular}{cccc}
\hline & Ubeji & & Alesa Eleme \\
\hline Days of sample & TOG Alone & TOG with Axonopus sp. & TOG alone \\
\hline 1 & $4.60 \pm 0.12$ & $4.60 \pm 0.120$ & $4.66 \pm 0.096$ \\
30 & $4.89 \pm 0.202$ & $6.25 \pm 0.320^{*}$ & $4.88 \pm 0.022$ \\
60 & $5.13 \pm 0.168$ & $6.66 \pm 0.241^{*}$ & $5.14 \pm 0.158$ \\
90 & $5.15 \pm 0.089$ & $6.87 \pm 0.078^{*}$ & $5.17 \pm 0.093$ \\
120 & $5.19 \pm 0.062$ & $6.87 \pm 0.207^{*}$ & $5.21 \pm 0.096 \pm 0.67^{*}$ \\
\hline
\end{tabular}

* significance difference exists between soil with Axonopus sp. treatment and those without at p $>0.05$. Values are means \pm standard error of three replicates.

Eleme revealed 66\% reduction in TOG by Axonopus sp (see Table 3).

A comparison of petroleum hydrocarbon loss in the soil of Ubeji in Delta state and Alesa Eleme in Rivers state showed $2415.82 \mathrm{mg} / \mathrm{kg}$ at Ubeji and $2415.74 \mathrm{mg} / \mathrm{kg}$ at Alesa Elema loss of TOG (see Table 1), indicating a difference of 0.08 . This however showed no significant difference in TOG loss in the soils of these communities as a result Axonopus sp. This is evident from Table 3 that showed a calculated t value of 0.991 and critical tvalue of 2.776 with 4 degrees of freedom for a two-tailed test at 0.05 significant level, and correlation coefficient of 0.996 at $p>0.05$. Since the calculated $t$ is lower than the critical $t$, it showed that there is no significant difference in the loss of petroleum hydrocarbon in the soil of Ubeji and Alesa Eleme. This could be ascribed to the fact that these communities are located within the Niger Delta region of Nigeria that experiences similar soil properties 


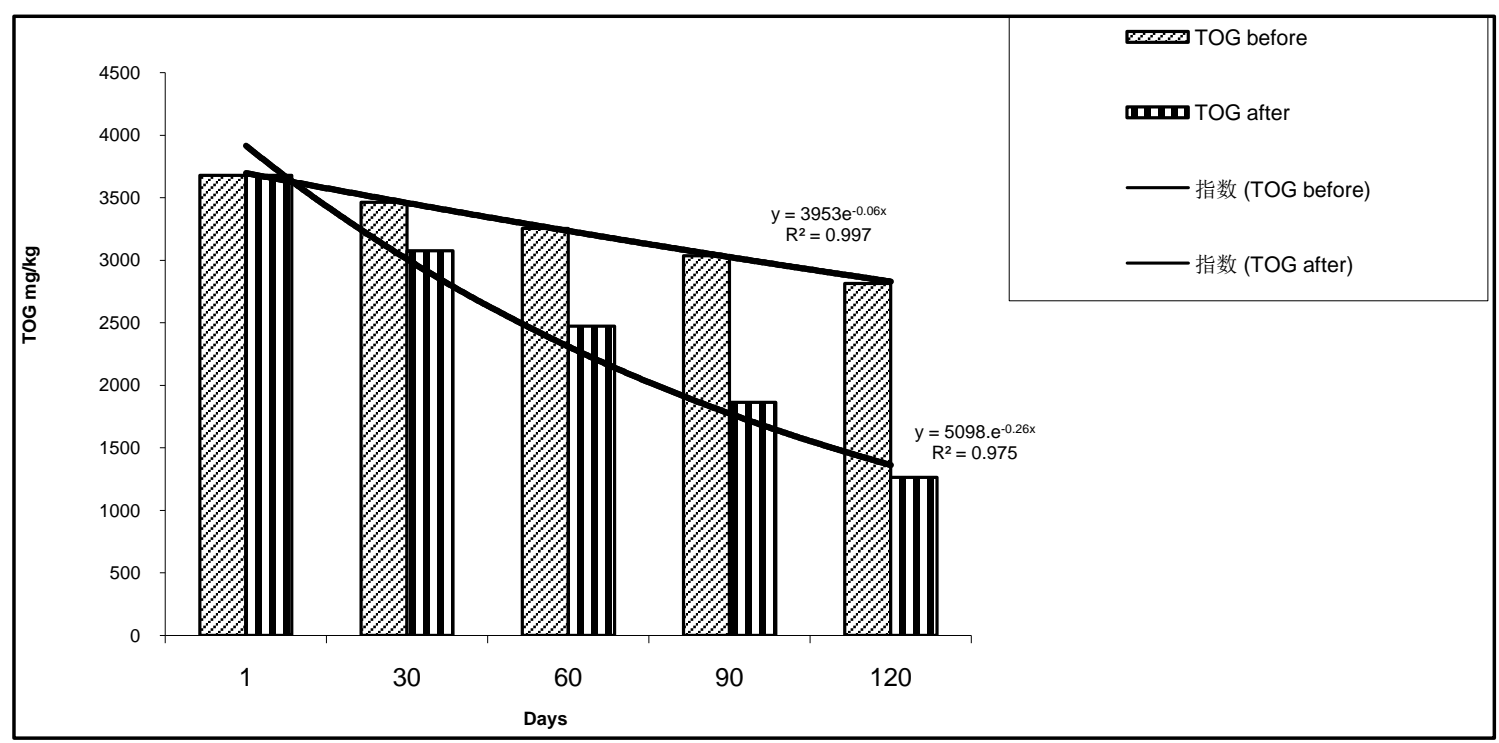

Figure 3. Axonopus sp. effect on the concentration of hydrocarbon in soil in Ubeji.

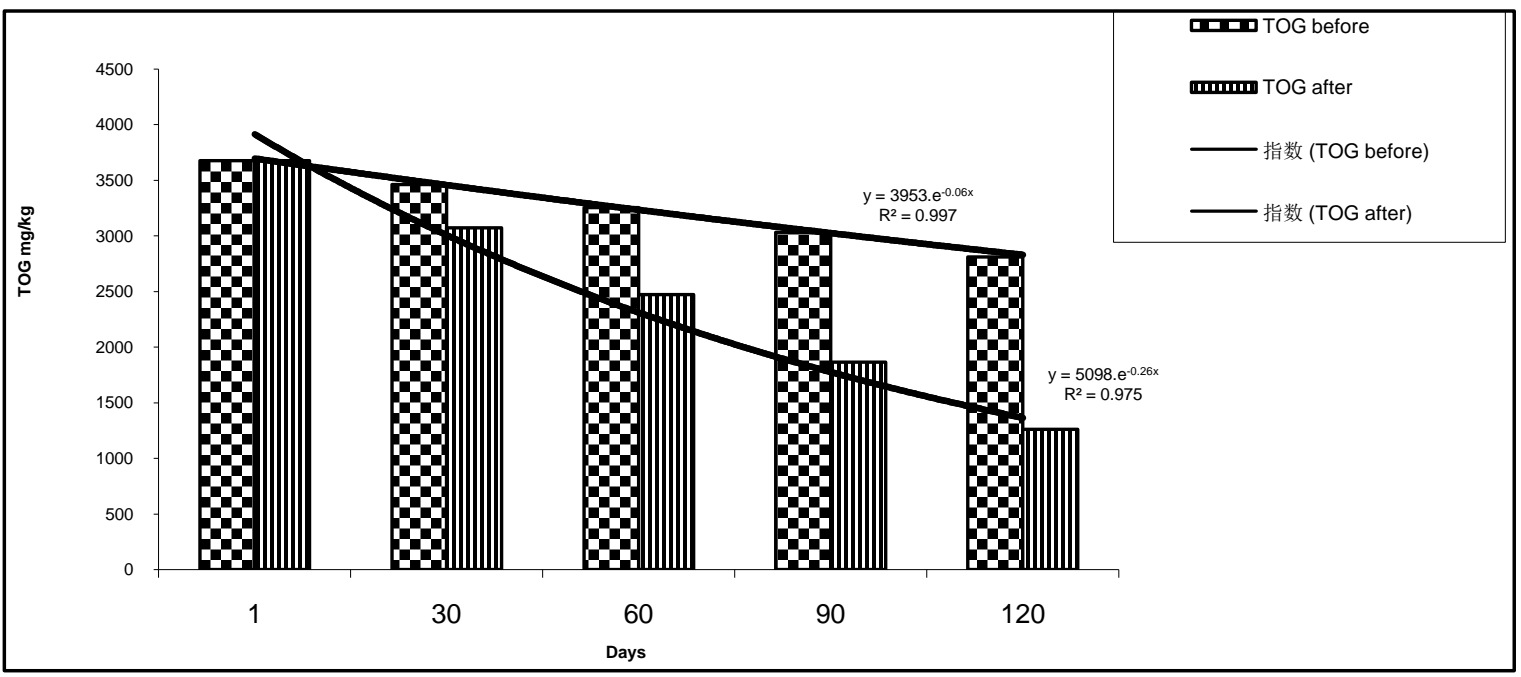

Figure 4. Axonopus sp. effect on the concentration of hydrocarbon in soil in Alesa Eleme.

and climate. The implication of this result is that Axonopus $s p$. has the tenacity to reduce/phytoremediate TOG concentration in soil of any geographical region of the world.

Table 4 showed the use of Axonopus sp. in the reduction of crude oil in impacted soils. Generally from Table 4, the growth of Axonopus sp. in the crude oil impacted soils of Ubeji and Alesa Eleme in the Niger Delta region of Nigeria has reduced the acidity of hydrocarbon content in soil. There was a gradual reduction of acidity from the first day to the $90^{\text {th }}$ days of experiment $(4.46-6.87$ $\mathrm{pH}$ in Ubeji and 4.66 - $6.86 \mathrm{pH}$ in Alesa Eleme), thereafter there was a stabilization at the $4^{\text {th }}$ months. However the is slight reduction in acidity in soils with Axonopus $s p$. in both communities even until the $4^{\text {th }}$ months. This shows that Axonopus sp. quickened the phytoremediation process of TOG from impacted soil. This result also corroborated that of [9] with the use of Glycine max for the removal of the effect of crude oil on the physico-chemical properties of soil. There was a general significant difference in the $\mathrm{pH}$ values of the soils with Axonopus sp. and of those without Axonopus sp. This is evident from $\mathrm{t}$ $=3.92$ and $\mathrm{r}=0.971$ for soils of Ubeji and $\mathrm{t}=3.95$ and $\mathrm{r}$ $=0.94$ for Alesa Eleme at $p>0.05$ which is greater than the critical $t=2.776$, and this indicate a positive correlation in these soils. However comparing the content of TOG in soils with Axonopus sp. and their corresponding $\mathrm{pH}$ values, it showed that $\mathrm{pH}$ values increases with decrease in crude oil content, and a negative correlation of -0.853 for Ubeji and -0.845 for Alesa Eleme at $\mathrm{p}>0.05$. This indicates that acidity in soil increases with increase in the concentration of crude oil in soil, this is because of 
the fact that the higher the $\mathrm{pH}$ values, the lower the acidity. This finding corroborated the work of $[9,27,45]$. The continue increase in soil $\mathrm{pH}$ up to the $3^{\text {rd }}$ months is an indication that there was a conducive environment for soil bacteria and biodegradation [9,46].

Table 5 revealed that there is reduction in organic matter content of soils with Axonopus sp. than those without Axonopus sp. in Ubeji and Alesa Eleme in the first 30 days. This reduction could be the low release of carbon at the first month, and as such the Axonopus sp. now impact directly on the soils. On the other hand, the growth of Axonopus sp. from the 60 days enhanced the accumulation of organic matter in the soils. This finding corroborated those of [9] in his study of G. max and ascribed the enhanced accumulation of organic matter to shielding of leaves from after the 42 days and the decomposition of such leaves increased the organic matter composition of the vegetated soil more than the nonvegetated soil. The continuous release of carbon into the soil also enhanced the accumulation of organic matter content of soil. Crude oil content in soil correlate significance $(\mathrm{r}=-0.52$ and $\mathrm{t}=21.23)$ with organic matter content of the soil at $\mathrm{p}<0.5$, this indicate that as crude oil content in soil increases, there is a corresponding decrease in organic matter of soil in Ubeji and Alesa Eleme.

There was a general enhancement of moisture in the soil as a result of the treatment with Axonopus sp. at Ubeji and Alesa Eleme (see Table 6). This result corro- borated the result of [9] with 75 g crude oil with G.max, but differs from those with 25/54 g crude oil with G.max. However there is a marked difference in soil moisture in soil with Axonopus sp. and those with crude oil alone except at the initial day of observation. For instance at the end of the 120 days of observation, a difference of $7.21 \%$ and $7.23 \%$ of moisture was observed in soil with Axonopus sp. and those with crude oil alone at Ubeji and Alesa Eleme respectively. This is further confirmed by $\mathrm{r}$ $=0.869(\mathrm{t}=3.958)$ and $\mathrm{r}=0.940(\mathrm{t}=2.506)$ at $\mathrm{p}>0.05$ for Ubeji and Alesa Eleme respectively. This showed a positive correlation, which indicates that as crude oil in soil increases; there is a decrease in soil moisture content. The higher content of moisture content in soil with Axonopus sp. and those with crude oil alone could be ascribed to the inhibition of root growth, which often lead to low penetration of water and higher accumulation of water on the soil surface [9]. Also the crude causes reduction in transpiration and thus reduces the rate of water absorption and uptake [47].

\section{Conclusion}

The study has demonstrated that Carpet grass Axonopus sp. and its associated micro organisms have the tenacity to reduce the concentration of hydrocarbon in an impacted soil. It showed that there was a gradual loss in the concentration of hydrocarbon in soil from the beginning to the end of the experiment at Ubeji and Alesa Eleme

Table 5. Effect of Axonopus sp. on the percentage organic matter of oil polluted soil.

\begin{tabular}{ccccc}
\hline \multicolumn{1}{c}{ Ubeji } & & Alesa Eleme & \\
\hline Days of sample & TOG alone & TOG with Axonopus sp. & TOG alone & TOG with Axonopus sp. \\
\hline 1 & $3.18 \pm 0.123$ & $3.18 \pm 0.105$ & $3.18 \pm 0.103$ & $3.18 \pm 0.116$ \\
30 & $2.24 \pm 0.560$ & $2.09 \pm 0.320^{*}$ & $2.25 \pm 0.100$ & $2.11 \pm 0.108^{*}$ \\
60 & $2.03 \pm 0.133$ & $3.36 \pm 0.241^{*}$ & $2.06 \pm 0.261$ & $3.36 \pm 0.016^{*}$ \\
90 & $1.89 \pm 0.123$ & $3.39 \pm 0.006^{*}$ & $1.90 \pm 0.153$ & $3.41 \pm 0.301^{*}$ \\
120 & $1.93 \pm 0.025$ & $3.39 \pm 0.101^{*}$ & $1.92 \pm 0.111$ & $3.41 \pm 0.002^{*}$ \\
\hline
\end{tabular}

* significance difference exists between soil with Axonopus sp. treatment and those without at $\mathrm{p}>0.05$. Values are means \pm standard error of three replicates.

Table 6. Effect of Axonopus sp. on the percentage moisture content of oil polluted soil.

\begin{tabular}{ccccc}
\hline \multicolumn{1}{c}{ Ubeji } & \multicolumn{3}{c}{ Rumiekpe } \\
\hline Days of sample & TOG alone & TOG with Axonopus sp. & TOG alone & TOG with Axonopus sp. \\
\hline 1 & $5.20 \pm 0.760$ & $5.20 \pm 0.650$ & $5.23 \pm 0.650$ & $5.21 \pm 0.122$ \\
30 & $6.33 \pm 0.805$ & $13.58 \pm 0.890^{*}$ & $6.32 \pm 0.800$ & $6.60 \pm 0.650^{*}$ \\
60 & $7.60 \pm 0.060$ & $15.95 \pm 0.562^{*}$ & $7.63 \pm 0.133$ & $15.92 \pm 0.320^{*}$ \\
90 & $8.87 \pm 0.603$ & $16.08 \pm 0.121^{*}$ & $8.86 \pm 0.051$ & $16.09 \pm 0.124^{*}$ \\
120 & $8.87 \pm 0.011$ & $16.08 \pm 0.103^{*}$ & $8.86 \pm 0.115$ & $16.09 \pm 0.006^{*}$ \\
\hline
\end{tabular}

* significance difference exists between soil with Axonopus sp. treatment and those without at $\mathrm{p}>0.05$. Values are means \pm standard error of three replicates. 
respectively. Generally, there was $66 \%$ loss of hydrocarbon at the end of the four months' observation in both Ubeji and Alesa Eleme as a result of Axonopus sp. However, there is no significant difference in crude oil loss in the soils of Ubeji and Alesa Eleme as a result of Axonopus sp. This could be ascribed to the similarities in soil properties and climate type of the Niger Delta region of Nigeria. It is also revealed that acidity in soil decreases with increase in the concentration of crude oil in soil. On the other hand, the adoption of Axonopus sp. has enhanced the accumulation of organic matter and moisture content in oil-impacted soils of Ubeji and Alesa Eleme. And as crude oil concentration in soil increases, there is a decrease in organic matter and moisture content in soil. On the premise of these findings, the study therefore suggests that Axonopus sp. should be adopted for the remediation of oil-impacted soils.

\section{REFERENCES}

[1] National Research Council, "Oil in the Sea, Inputs, Fates, and Effects,” National Academy Press, Washington DC, 1985, pp. 7-10.

[2] UN Report, "Protecting Ecosystem for people and Planet," United Nations Environmental Programme, 2001, pp. 30147.

[3] W. C. Dabbs, “Oil Production and Environmental Damage," 1996. http://www.american.edu.TED/hpl.htm

[4] G. C. Okpokwasili and L. O. Odokuma, "Effect of Salinity on Biodegradation of Oil Spill Dispersants," Waste Management, Vol. 10, No. 2, 1990, pp. 141-146. http://dx.doi.org/10.1016/0956-053X(90)90118-5

[5] L. O. Odokuma and M. N. Ibor, "Nitrogen Fixing Bacteria Enhanced Bioremediation of Crude Oil Polluted Soil," Global Journal of Pure Applied Science, Vol. 8, No. 4, 2002, pp. 455-468.

[6] O. E. Inoni, D. G. Omotor and F. N. Adun, "The Effect of Oil Spillage on Crop Yield and Farm Income in Delta State, Nigeria,” Journal of Central European Agriculture, Vol. 7, No. 1, 2006, pp. 41-49.

[7] A. I. Etang, "The Nigerian State Oil Exploitation and Community Interest: Issues and Perspectives,” University of Port Harcourt Press, Port Harcourt, 1997.

[8] C. M. Frick, R. E. Farrell and J. J. Germida, “Assessment of Phytoremediation as an in Situ-Technique for Cleaning Oil-Contaminated Sites," Petroleum Technology Alliance, Calgary, 1999. http://www.rtdf.org/pub/phyto/phylinks.htm

[9] K. L. Njoku, M. O. Akinola and B. O. Oboh, "Phytoremediation of Crude Oil Contaminated Soil: The Effect of Growth of Glycine Max on the Physico-Chemical and Crude Oil Contents of Soil," Nature and Science, Vol. 7, No. 10, 2009, pp. 79-87.

[10] S. I. Efe and A. E. Okpali, "Management of Petroleum Impacted Soil with Phytoremediation and Soil Amendments in Ekpan Delta State, Nigeria," Journal of Environmental Protection, Vol. 3, No. 5, 2012, pp. 386-393.

\section{http://dx.doi.org/10.4236/jep.2012.35048}

[11] S. Lundstedt, "Analysis of PAHs and Their Transformation Products in Contaminated Soil and Remedial Processes,” Solfjodern Offset AB, Umea, 2003.

[12] J. Tang, X. Niu, Q. Sun and R. Wang, "Bioremediation of Petroleum Polluted Soil by Combination of Ryegrass with Effective Microorganisms," Journal of Environmental Technology and Engineering, Vol. 3, No. 2, 2010, pp. 8086.

[13] H. L. Yuan, J. S. Yang, Z. S. Wang, B. Z. Li, L. Zhang and R. Z. Lin, "Microorganism Screening for Petroleum Degradation and Its Degrading Characteristics," China Environmental Science, Vol. 23, No. 2, 2003, pp. 157161.

[14] H. S. Joo, P. M. Ndegwa, M. Shoda and C. G. Phae, "Bioremediation of Oil-Contaminated Soil Using Candida Catenulata and Food Waste," Environmental Pollution, Vol. 156, No. 3, 2008, pp. 891-896. http://dx.doi.org/10.1016/j.envpol.2008.05.026

[15] S. A. Trapp, S. Ucisik, D. Romano and M. Larsen, “The Role of Plants and Bacteria in Phytoremediation-Kinetic Aspects Bioremediation of Soils Contaminated with Aromatic Compounds in NATO Science Series IV," Earth Environmental Science, Vol. 76, 2007, pp. 41-49.

[16] M. K. Banks, H. Mallede and K. Rathbone, "Rhizosphere Microbial Characterization in Petroleum-Contaminated Soil," Soil Sediment Contamination, Vol. 12, No. 3, 2003, pp. 371-385.

[17] J. Wang, Z. Z. Zhang, Y. M. Su, W. He, F. He and H. G. Song, "Phytoremediation of Petroleum Polluted Soil," Petroleum Science, Vol. 5, No. 2, 2008, pp. 167-171. http://dx.doi.org/10.1016/S0065-2113(08)60179-0

[18] Y. Chan, G. H. Li, X. Zhang, X. X. Lu and L. Zhang, "Effect of Petroleum Biodegradation and Rhizosphere Micro Eco-System in Phytoremediation of the Polluted Soil in Oilfield," Journal of Tsinghua University (Science and Technology), Vol. 45, No. 6, 2005, pp. 784-787.

[19] S. D. Cunningham, A. T. Aderson, A. P. Schwab and F. C. Hsu, "Phytoremediation of Soil Contaminated with Organic Pollutant,” Advanced Agronomist, Vol. 56, 1996, pp. 55-114. http://dx.doi.org/10.1016/S0065-2113(08)60179-0

[20] A. P. Schwab and M. K Banks, "Biologically Mediated Dissipation of Polyaromatic Hydrocarbons in the Root Zone Bioremediation through Rhizosphere Technology,” American Chemical Society, Washington DC, 1994, pp. 363-375. http://dx.doi.org/10.1021/bk-1994-0563.ch012

[21] A. P. Schwab and M. Bank, "Phytoremediation of Petreoleum Contaminated Soils,” In: D. C. Andriano, J. M. Bollag, W. T. Frankenberger Jr. and R. C. Sims, Eds., Bioremediation of Contaminated Soils, American Society of Agronomy, Crop Science Society of America, Soil Science Society of America, Madison, 1999, pp. 783-795.

[22] N. Merkl, "Phytoremediation of Petroleum-Contaminated Soil,” Margraf Publisher, Weikershim, 2005.

[23] P. Schroder, P. J. Harvey and J. P. Schwitzguebel, "Prospects for the Phytoremediation of Organic Pollutants in Europe," Environmental Science Pollution Research, Vol. 
9, No. 1, 2002, pp. 1-3. http://dx.doi.org/10.1007/BF02987312

[24] B. E. Pivetz, "Phytoremediation of Contaminated Soil and Ground Water at Hazardous Waste Sites,” Man Tech Environmental Resources Services Corporation, Ada, 2001, p. 36.

[25] D. E. Salt, M. Blaylock, N. P. Kumar, V. Dushenkov, B. D. Ensley, I. Chet and I. Raskin, "Phytoremediation: A Novel Strategy for the Removal of Toxic Metals from the Environment Using Plants,” Bio/Technology, Vol. 13, 1995, pp. 468-474.

[26] J. L. Schnoor, L. A. Licht, S. C. McCutcheon, N. L. Wolfe and L. H. Carreira, "Phytoremediation of Organic and Nutrient Contaminants," Environmental Science Technology, Vol. 29, 1995, pp. 318-323.

[27] J. M. Ayotamuno, R. B. Kogbara and P. N. Egwuenum, "Comparison of Corn and Elephant Grass in the Phytoremediation of Petroleum-Hydrocarbon Contaminated Agriculture Soil in Port Harcourt, Nigeria,” Journal of Food, Agriculture and Environment, Vol. 4, No. 3 \& 4, 2006, pp. 218-222.

[28] S. I. Efe, "Gas Flaring and the Niger Delta Environment: A Climatological Analysis,” African Journal of Environmental Studies, Vol. 3, No. 1 \& 2, 2002, pp. 11-17.

[29] I. J. Alakpodia, “The Environment of the Niger Delta,” In: B. C. Uweru and J. O. Ubrurhe, Eds., Readings in General Studies, Nigerian People and Culture, About Research Publisher, Warri, 2000, pp. 190-203.

[30] S. I. Efe, "The Relationship between Gas Flaring and the Spatial Variation of Acid Rain in Nigeria," Africa Geosciences Review France, Vol. 318, No. 3 \& 4, 2011, pp. 4759.

[31] S. I. Efe, "Effect of Gas Flaring on Temperature and Adjacent Vegetation in Niger Delta Environment," International Journal of Environmental Issues, Vol. 1, No. 1, 2003, pp. 91-101.

[32] D. Eckert and J. T. Sims, "Recommended Soil pH and Lime Requirement Tests,” In: J. T. Sims and A. Wolfe, Eds., Recommended Soil Testing Procedures for the Northeastern United States. Northeast Regional Bulletin 493, Agricultural Experiment Station, University of Delaware, Newark, pp. 11-16.

[33] K. L Njoku, M. O. Akinola and B. O. Oboh, "Germination, Survival and Growth of Accessions of Glycine Max L. (Merrill) (Soybean) and Lycopersicon esculentum L. (Tomato) in Crude Oil Polluted Soil," Research Journal of Environmental Toxicology, Vol. 2, No. 2, 2008, pp. 7784. http://dx.doi.org/10.3923/rjet.2008.77.84

[34] J. Schneekloth, T. Bauder, R. Broner and Wakson, "Measurement of Soil Moisture,” 2002.

[35] A. Walkey and I. A. Black, "Determination of Organic Carbon in Soil,” Soil Science, Vol. 37, 1934, p. 29.

[36] J. C. Okolo, E. N. Amadi and C. T. I. Odu, "Effects of Soil Treatments Containing Poultry Manure on Crude Oil Degradation in Sandy Loam Soil," Applied Ecology and Environmental Research, Vol. 3, No. 1, 2005, pp. 47-53.
[37] S. McClutchen and J. Schnoor, "Phytoremediation Transformation and Control of Contaminants,” John Wiley and Sons Inc., Hoboken, 2003.

[38] M. Escalante-Espinosa, M. E. Gallegos-Martinez, E. Favela Torres and M. Gutierrez-Rojas, "Improvement of the Hydrocarbon Phytoremediation Rate by Cyperus laxus Lam. Inoculated with a Microbial Consortium in a Model System," Chemosphere, Vol. 59, No. 3, 2005, pp. 405413. http://dx.doi.org/10.1016/j.chemosphere.2004.10.034

[39] L. A. Phillips, C. W. Greer and J. J. Germida, "CultureBased and Culture-Independent Assessment of the Impact of Mixed and Single Plant Treatments on Rhizosphere Microbial Communities in Hydrocarbon Contaminated Flare-Pit Soil,” Soil Biology \& Biochemistry, Vol. 38, No. 9, 2006, pp. 2823-2833. http://dx.doi.org/10.1016/j.soilbio.2006.04.038

[40] K. Eulis, C. Ho, A. P. Schwah, S. Rock and M. K. Banks, "Greenhouse and Field Assessment of Phytoremediation for Petroleum Contaminant in a Riparian Zone," Bioresource Technology, Vol. 99, No. 6, 2008, pp. 1961-1971.

[41] L. A. Phillips, W. G. Charles, R. E. Farrell and J. J. Germida, "Field-Scale Assessment of Weathered Hydrocarbon Degradation by Mixed and Single Plant Treatments," Applied Soil Ecology Vol. 42, No. 1, 2009, pp. 9-17. http://dx.doi.org/10.1016/j.apsoil.2009.01.002

[42] J. Gurska, W. X. Wang, K. E. Gerhardt, A. M. Khalid, D. M. Isherwood, X. D. Huang, B. R. Glick and B. M. Greenberg, “Three Year Field Test of a Plant Growth Promoting Rhizobacteria Enhanced Phytoremediation System at a Land Farm for Treatment of Hydrocarbon Waste," Environmental Science \& Technology, Vol. 43, No. 12, 2009, pp. 4472-4479.

[43] Z. Z. Zhang, S. M. Su, Y. J. Luo and M. Lu, "Improvement of Natural Microbial Remediation of Petroleum-Polluted Soil Using Graminaceous Plants,” Water Science and Technology, Vol. 29, No. 5, 2009, pp. 1025-1035. http://dx.doi.org/10.2166/wst.2009.081

[44] L. Xin, X. J. Li, P. J. Li, F. Li, Z. Lei and Q. X. Zhou, "Evaluation of Plant-Microorganism Synergy for the Remediation of Diesel Fuel Contaminated Soil,” Bulletin of Environmental Contamination and Toxicology, Vol. 81, No. 1, 2008, pp. 19-24. http://dx.doi.org/10.1007/s00128-008-9438-1

[45] M. L. Andrade, E. F. Covelo, F. A. Vega and P. Marcet, "Effect of the Prestige Oil spill on Salt Marsh Soil on the Coast of Galicia (Northwestern Spain)," Journal of Environmental Quality, Vol. 33, No. 6, 2004, pp. 2103-2110. http://dx.doi.org/10.2134/jeq2004.2103

[46] J. T. Dibble and R. Bartha, "Rehabilitation Oil-Inundation Agricultural Land: A Case History,” Soil Science, Vol. 128, No. 1, 1979, pp. 56-60. http://dx.doi.org/10.1097/00010694-197907000-00009

[47] M. Kent, “Advanced Biology,” Oxford University Press, Oxford, New York, 2000, pp. 276-277. 